\title{
THE SYMBOLISM OF THE EARTH IN THE POEMS BY M.I. TSVETAEVA
}

\author{
Marina V. Pimenova \\ University of the Foreign Languages, Saint Petersburg, Russia
}

Saule S. Dutbaeva

Atyrau State University named after Kh. Dosmukhamedov, Atyrau, Kazakhstan

Elena A. Moshina

Military Academy of Logistics named after Army General A.V. Khrulev, Saint Petersburg, Russia

\begin{abstract}
The article considers the poems by Marina Tsvetaeva in the aspect of elemental symbolism. The article aims to describe traditional for Russian linguistic culture and individual author's symbolism of the earth in M.I. Tsvetaeva's poems. The choice of the research object stipulates scientific novelty of the study, which was fulfilled applying descriptive and conceptual research methods. It has been noted, that the symbols, traditionally assigned to Russian linguistic culture, are represented in the poems by Tsvetaeva as pre-Christian: the earth is described by the poetess as a place of habitation, residence, Motherland, a house, arable land; the symbol of imperishability and support. The earth is one of the extrema - the lower and the upper points in vertical dimension, where the former denotes the ground and the Man as opposed to the latter, nominating the Heaven and the Creator. The ground is a Christian symbol of modesty, it is associated with death, ashes, a grave pit. The analysis undertaken has enabled to reveal individual author's symbols of the earth: earth - rock / stone; earth - mountain, unknown land - the sea, the earth - the air, the salt of the earth - talented people / victim. It has been shown, that the author's perception of a particular worldview fragment supplements the conceptual structure of macro concept "earth" with characteristics, which are not included into the structure of national concept.
\end{abstract}

Key words: symbol, image, myth, individually-author's picture of the world, linguistic culture, metaphor, lexis.

Citation. Pimenova M.V., Dutbaeva S.S., Moshina E.A. The Symbolism of the Earth in the Poems by M.I. Tsvetaeva. Vestnik Volgogradskogo gosudarstvennogo universiteta. Seriya 2. Yazykoznanie [Science Journal of Volgograd State University. Linguistics], 2020, vol. 19, no. 3, pp. 116-134. (in Russian). DOI: https://doi.org/ 10.15688/jvolsu2.2020.3.11

УДК 81 ' $42: 821.161 .1$

Дата поступления статьи: 18.11.2019

ББК 81.055 .52 Дата принятия статьи: 27.03.2020

\section{СИМВОЛИКА ЗЕМЛИ В ПОЭМАХ М.И. ЦВЕТАЕВОЙ}

\section{Марина Владимировна Пименова}

Институг иностранных языков, г. Санкт-Петербург, Россия

\section{Сауле Сергоевна Дутбаева}

Атырауский государственный университет им. Х. Досмухамедова, г. Атырау, Казахстан

\section{Елена Анатольевна Мошина}

Военная академия материально-технического обеспечения им. генерала армии А.В. Хрулева, г. Санкт-Петербург, Россия 
Аннотация. В статье рассматриваются поэмы Марины Ивановны Цветаевой в аспекте стихийной символики и ее речевого воплощения. Цель работы - с опорой на концептуальный анализ охарактеризовать традиционную для русской лингвокультуры и индивидуально-авторскую символику земли в поэмах М. Цветаевой. Выбор такого объекта определяет новизну исследования. Установлено, что в поэмах М. Цветаевой традиционные для русской лингвокультуры символы представлены дохристианскими (включая древнерусские и скандинавские) и христианскими символами: Земля - место обитания, проживания (голубая Отчизна, дом, семья); Земля - опора, символ незыблемости и нерушимости мира (твердыня); Земля - нижняя точка пространственной вертикали (соотносимая с первой частью оппозиций: земля - небо, земля / человек Бог); Земля - христианский символ скромности; Земля - символ смерти / праха / тлена; Соль земли - символ талантливых, одаренных людей. Выявлены индивидуально-авторские поэтические символы земли: земля скала / камень; земля - гора; (неведомая) земля - море; (новая) земля - воздух; кровь земли - талантливые, одаренные люди / жертва. Показано, как авторское осмысление фрагмента действительности дополняет концептуальную структуру макроконцепта «земля» признаками, не входящими в структуру национального концепта. Вклад авторов: М.В. Пименовой разработаны теоретические основы и методика исследования, обобщены результаты; С.С. Дутбаевой и Е.А. Мошиной осуществлен сбор языкового материала и его описание в соответствии с концепцией работы.

Ключевые слова: символ, образ, миф, индивидуально-авторская картина мира, лингвокультура, метафора, лексика.

Цитирование. Пименова М. В., Дутбаева С. С., Мошина Е. А. Символика земли в поэмах М.И. Цветаевой // Вестник Волгоградского государственного университета. Серия 2, Языкознание. - 2020. - Т. 19, № 3. C. 116-134.-DOI: https://doi.org/10.15688/jvolsu2.2020.3.11

\section{Введение}

Осмысление художественного текста в когнитивном аспекте как средства выражения ментального мира писателя, его знаний о действительности, воплощенных в произведении в виде индивидуально-авторской картины мира, весьма актуально в лингвистике. Каждый художник слова пользуется языковыми средствами, «вкладывая» свое видение и свое восприятие в ключевые концепты культуры и категории мира. Индивидуально-авторский концепт - единица «сознания поэта или писателя, которая получает свою репрезентацию в художественном произведении или совокупности произведений и выражает индивидуально авторское осмысление сущности предметов и явлений» [Беспалова, 2002, с. 6]. В связи с этим представляется значимым раскрытие художественного компонента макроконцепта «земля», репрезентированного в поэмах М. Цветаевой. Авторское осмысление того или иного фрагмента действительности дополняет концептуальную структуру признаками, не входящими в структуру национального концепта. Таким образом, исследование приоритетов автора в выборе тех или иных когнитивных признаков при актуализации значимых для него концептов позволяет сде- лать вывод об особенностях его индивидуально-авторской картины мира.

Изучению цветаевского творческого наследия посвящен ряд работ, затрагивающих различные аспекты: Н.А. Афанасьевой и О.Ю. Шишкиной описаны архетипы [Афанасьева, Шишкина, 2002]; М. Боров иковой подробно проанализирована поэтика произведений [Боровикова, 2007], Е.В. Волковой, В.А. Масловой, Е.А. Мошиной, М.В. Пименовой исследованы отдельные фрагменты индивидуально-авторской картины мира поэтессы [Волкова, 2018; Маслова, 2000; 2017; Мошина, 2019; Пименова, 2007; 2011; Пименова, Волкова, 2018]; В.Ю. Александровым, С.А. Безменовой рассмотрены вопросы циклизации в произведениях М. Цветаевой [Александров, 1983; Безменова, 1985]; В.Ю. Александровым, А.А. Бобровым и М.Г. Головей изучены особенности жанров в творчестве поэтессы [Александров, 1983; Бобров, 2008; Головей, 2011], И.И. Бабенко охарактеризованы коммуникативные особенности лексики [Бабенко, 2000], а Э.М. Береговской и Н.М. Вахтель - синтаксические фигуры [Береговская, 1998; Вахтель, 2002]. Однако в научной литературе отсутствуют работы, посвященные описанию символики земли и особенностей ее концептуализации в индивидуально-авторской картине мира М. Цветаевой. 


\section{МАТЕРИАЛЫ И СООБЩЕНИЯ}

Цель статьи - описать и интерпретировать авторские способы объективации символов земли в произведениях М. Цветаевой. Для достижения поставленной цели необходимо решить следующие задачи: 1) выделить символические признаки макроконцепта «земля»; 2) провести выборку лексических единиц, объективирующих символические признаки макроконцепта «земля» в авторской картине мира М.В. Цветаевой; 3) определить авторскую специфику реализации символических признаков макроконцепта «земля».

\section{Материал и методы исследования}

В качестве источников языкового материала для анализа взяты 14 поэм Марины Ивановны Цветаевой, написанных ею в период с 1914 по 1929 г.: «Чародей» (1914), «Царьдевица» (1920), «На красном коне» (1921), «Переулочки» (1922), «Молодец» (1922), «Поэма Конца» (1924), «Поэма Горы» (1924), «Крысолов» (1925), «С моря» (1926), «Попытка комнаты» (1926), «Поэма лестницы» (1926), «Новогоднее» (1927), «Поэма Воздуха» (1927), «Перекоп» (1929).

Основными методами исследования выступают описательный, интерпретативный, концептуальный. Обращение к макроконцепту «земля» мотивировано не только его высокой значимостью для русской лингвокультуры в целом, но и интересом к ярким образам авторской интерпретации земли.

Уточним базовые понятия и термины исследования. Под макроконцептом мы понимаем комплексное многоуровневое ментальное образование, которое объединяет разнородные пласты знаний об объектах и явлениях действительности (от конкретных до абстрактных). Эти знания могут быть представлены в виде мифологем, концептуальных признаков и самостоятельных концептов, объединенных в общую иерархическую структуру родо-видовыми отношениями.

Мифы и символы, к которым обращаются когнитивная лингвистика и лингвокультурология, позволяют по-новому оценить деятельность человеческого сознания и мироощущение в целом. Язык хранит мифы, в которых прочитывается символика древних концептов, скрывающих мифологемы. Мифоло- гема - это единица мифологического мышления, исходный символический образ, сюжет, обладающий целостностью, содержащий устойчивый комплекс определенных признаков.

В разных лингвокультурах существуют мифологемы, которые являются содержательными единицами языкового сознания. Они хранятся в коллективном бессознательном и базируются на архетипах сознания. В каждой национальной культуре мифологемы преломляются сообразно ментальности народа и воплощаются не только в мифах, но и в стереотипах, языковых схемах, когнитивных моделях, отражающих закрепленные формы мышления. Примерами мифологем могут быть такие разнородные понятия, как Дерево Мировое, божественная пара, потоп и пр. Мифологемы, по сути, есть древние концепты.

Макроконцепт «земля» относится к разряду символических. Предложенная В.В. Колесовым формула развития концепта «образ понятие - символ» [Колесов, 1992, с. 16] может быть пересмотрена применительно к отдельным концептуальным структурам. Существуют «концепты, в мотивирующих признаках репрезентантов которых уже заложен символ. То есть символ в структурах таких концептов - не заключительный этап их развития, а исходная точка. Под символическим понимается концепт, мотивирующие признаки которого восходят к известному или утраченному мифу; эти признаки разворачиваются в разном объеме в виде образных, понятийных, ценностно-оценочных и собственно символических признаков, но уже в другом объеме по отношению к другим концептам» [Пименова, 2011, с. 68].

Символика земли в русской лингвокультуре основывается как на христианских, так и на дохристианских (славянских) мифах и представлениях о земле. Анализ мифологических источников, словарей, языкового материала из Национального корпуса русского языка позволил определить понятийные и мотивирующие признаки макроконцепта «земля», в том числе символические. В структуре этого макроконцепта в русской лингвокультуре реализуются следующие мифологемы: 'земля живое существо', 'земля - мать', 'земля - богиня', 'земля - Родина', 'земля - дом', 'земля - пища / клятва / жертвоприношение', 
‘ земля - стихия / элемент', 'земля - могила', 'земля - прах / тлен / малоценное'.

\section{Результаты и обсуждение}

В анализируемых произведениях М. Цветаевой воплощены не все перечисленные выше мифологемы. Поэтесса использует и другие символы земли, берущие начало в древних мифах. В ее произведениях встречается авторская символика, эксплицируемая в формах и категориях русского языка. Рассмотрим их подробнее.

I. Анимизм и антропоморфизм являются характерными чертами архаичных культур независимо от национальной специфики. Земля представлялась людям, до принятия христианства обожествлявшим природу, живым человекоподобным существом. Травы, цветы, кустарники, деревья казались ее пышными волосами; горы и скалы были ее костями; цепкие корни деревьев заменяли жилы; кровью земли была сочившаяся из ее недр вода. Как живая, она стонала от боли в бурю, гневалась, учиняя землетрясения, улыбалась под солнцем, даря людям красоты, засыпала зимой и пробуждалась весной, умирала, обожженная засухой, и возрождалась после дождей. В произведениях М. Цветаевой вербализованы соматические признаки земли, например 'кровь':

(1) Наша кровь - та же смоль! / Раз кровь кровью смой! / Пусть ропщут умы, - / Все ж кровь земли - мы! (Крысолов);

'хребет':

(2) То вскачь по хребтам наклонным, / То снова круть. / За красным, за красным конным / Все тот те путь (На красном коне).

М. Цветаева наделяет землю не только физиологическими свойствами живого существа (человека), но и человеческими чертами. Земля-мать - известная мифологема, широко распространенная в разных культурах. В русской лингвокультуре до сих пор сохраняется устойчивое выражение мать-земля и его вариации земля - матушка, кормилица, мать сыра земля ${ }^{1}$.

Для цветаевских поэм характерна авторская реализация гендерных признаков материнства. Если в русской лингвокультуре клю- чевыми для актуализации дохристианского восприятия земли являются слова мать (и производные от него), кормилица и слова, выражающие признаки рождающей и плодоносящей почвы, то у М. Цветаевой находим контексты с отрицанием этих признаков в описаниях периодов истории страны, когда в России царили хаос, разруха и голод:

(3) В ломо́ту / Жатв - зачем рождаем? / ...Всем неумолотом, / Всем неурожаем / Верха... По расщелинам / Сим - ни вол ни плуг. / - Землеотлучение (Поэма Воздуха).

Земля в войну перестает быть матерью, потому что утрачивает своих детей:

(4) Матери под стопками / Детскими... (Поэма Воздуха).

Перемены, наступившие в мире, приводят к рубежу, завершению целого этапа жизни, финишная точка которого воспринимается как конец всем надеждам, ожиданиям и чаяниям, конец терпению. Люди бегут с родной земли на чужбину, как пришлось уезжать и Марине Цветаевой. Чужбина не стала ей матерью. Не рождавшая ребенка мать - это мачеха. Чужая земля - не родная мать - стала мачехой для поэтессы, как и для многих покинувших Россию людей:

(5) Есть - да нету нам! / Мачеха - не мать! / Дальше некуда. / Здесь околевать (Поэма Горы).

II. В исследуемых произведениях М. Цветаевой обнаруживаются семантические связи между словами, называющими ритуальные практики, источником которых является дохристианская культура. Это, например, ассоциация земли с пищей. Пищевой код русской лингвокультуры прочитывается в вариантах выражений есть / жрать / грызть землю. В них видятся отголоски древнего славянского ритуала клясться / заклинать / проклинать матерьюземлей. Такую клятву считали самой правдивой и надежной. Цветаевская интерпретация этого ритуала тройственна.

1. Земля - это источник жизненных сил ${ }^{2}$.

2. Чужбина - не Родина, сил человеку не прибавляет. В описании трудных лет эмиг- 


\section{МАТЕРИАЛЫ И СООБЩЕНИЯ}

рации М. Цветаева обыгрывает глагол глодать, передавая им значение «голод»:

(6) На то и сына родила, / Прах дольний гло́жа - / Чтоб из-под орльего крыла / Мне взял - гром Божий! (На красном коне).

Прах дольний - земля под ногами - уже не опора, потому что человек низвержен, он упал, он не стоит на собственных ногах - он гложет землю.

3. Другая религия или культура обрывают связь с родной землей, семьей. Таким способом описывается монашество:

(7) На миру монашество - / Что землю грызть! / Ну, а бабья наша тут / Молчать - корысть. / Ночь третья (Царь-девица).

Здесь выражение грызть землю означает «стиснуть зубы, терпеть».

Известно, что для мифологического сознания древних пища имела сакральное значение, являясь частью ритуала жертвоприношения. В жертву земле приносят зерно, которое в нем умирает и возрождается в новых побегах:

(8) Разломано небо! - Благой знак: / Заря кровянит шлем мой! / Солдаты! До неба - один шаг: / Законом зерна́ - в землю! (На красном коне).

В авторской картине мира М. Цветаевой земля, как пища, имеет вкус:

(9) Ой, долго ли? Ой, скоро ли? / Нуда, нуда, нуда / Все вялено, все солоно: / Земля, вода, еда (Перекоп).

Еще одна известная метафора - соль земли - встречается в поэме М. Цветаевой «Крысолов»:

(10) Наша соль - пыль от пуль! / Наша быль рваный куль! / Пусть злее чумы, - / Все ж соль земли - мы! (Крысолов).

Выражение соль земли - это аллюзия на текст Библии. В «Нагорной проповеди» (Евангелие от Матфея) читаем: «Вы есте соль земли. Аще же соль обуяет, чим осолится?» (Мф. 5:13-16). Со слов апостола, солью земли называют лучших людей, тех, кто придает жизни вкус и смысл.

Представление земли в образе символа русского гостеприимства «хлеб-соль» - это авторская находка М. Цветаевой:
(11) Солоницами - глазницы / У ржаной земли. / Что ж вы, гости имениты, / Мало по - были? (Переулочки).

Для славян двумя сакральными продуктами были хлеб и соль. Слившиеся воедино (хлебсоль), они стали олицетворением обильного угощения, гостеприимства, радушия. Хлебом-солью встречали, чествовали, величали, начинали новую жизнь в новом доме, благословляли молодых на свадьбе, отгоняли нечистую силу.

III. Пространственная оппозиция «этот мир - земля : тот свет - небо» представляется в аспекте вертикали - вектора-взгляда, устремленного ввысь:

(12) Выше!.. / Всем нам на «тем свету» / С пустотою сращать пяту/ Тяготенную (Попытка комнаты).

Небо необитаемо (пустотою), человек попирает пято́й землю, врастая в нее через земное притяжение (сращзать пяту тяготенную). Бог покинул небо, оставив человека один на один с самим собою. Он перестал быть спасителем. В мир пришли пытки, расстрелы и казни - смерть; дома опустели, как и небо над ними:

(13) Пол - для ног. / - Как внедрен человек, как вкраплен! - / Чтоб не капало - потолок. / Помнишь, старая казнь - по капле / В час? Трава не росла бы в дом - / Пол, земля не вошла бы в дом - / Всеми теми - кому и кол / Не препятствие ночью майской! (Попытка комнаты).

По-цветаевски, обитаемость дома прямо зависит от обитаемости неба. Бог-защитник покинул небеса, потому что человек перестал в него верить. Бесприютность, неприкаянность, скитальчество - удел человека, переставшего смотреть в небо, следовательно, переставшего видеть Бога.

IV. В индивидуально-авторской картине мира М. Цветаевой земля - это основа созидания, одна из четырех стихий, из которых состоит весь сотворенный мир:

(14) Силы - власти - престолы - славы - Стан пернатый и стан шершавый, / Ветер - во́ды - огонь земля, / Эта спящая кровь - моя! (Царь-девица).

В ее авторской картине мира граница этих стихий размыта: они плавно перетекают одна в другую ${ }^{3}$. 
В цветаевских поэмах авторский символизм земли сопряжен с другими стихиями. В поэме «Новогоднее» М. Цветаева море называет неведомой землей:

(15) До знакомства! < ..> / С мне-самой неведомой землею - / С целым морем... (Новогоднее).

В «Поэме Воздуха» появляется еще один символ непознанного: воздух - новая земля:

(16) Как Колумб здороваюсь / С новою землей - Воздухом (Поэма Воздуха).

Поэтесса обращается к стихии, связанной с рождением, и кажется, что воздух именно та стихия, которая согласуется с ее внутренним ритмом:

(17) Полная срифмованность. / Ритм, впервые мой! (Поэма Воздуха).

Стихии сосуществуют, они неразрывны, образуя основу мира. Воздух у М.И. Цветаевой ассоциируется с памятью, а память - с землей:

(18) Ходячие / Истины забудь! / С сильною отдачею / Грунт, как будто грудь / Женщины под стоптанным / Вое-сапогом (Поэма Воздуха).

У слова земля есть большое количество синонимов, один из которых - слово грунт. В военный период земля, по М. Цветаевой, становится грунтом. Слово грунт в русском языке многозначно: это верхний слой земли - почва; это морское дно; это промежуточный слой картины, на который еще не нанесен рисунок. Попранная сапогами земля не почва, на ней в войну ничего не растет. По морскому дну сапогами не наступают - глубоко. Остается последний смысл-загрунтованноепространство будущей картины. Этот смысл тоже отторгается цветаевским контекстом. Символ грунтаземли помогает понять словосочетание скальный грунт. Скала - это гора, на каменной поверхности которой ничего не растет (Грунт, как будто грудь Женщины). Женщина, потерявшая своих детей, сама символически умирает. А камень в русской лингвокультуре относится к разряду стихий и символизирует смерть.
Сплетенность и противоборство стихий мы встречаем в последующих строках:

(19) Словно моря противу // (Противу: читай - / По́ сердцу!) сплечением / Толп. - Гераклом бьюсь! / - Землеизлучение. / Первый воздух - густ (Поэма Воздуха).

Здесь оппозицию морю составляют три стихии - воздух, земля и огонь, причем две последние стихии слились в одну (Землеизлучение). Земля уподобляется солнцу, испускающему лучи.

«Поэма Воздуха» как дыхание - М. Цветаева считает вздохи (Первый воздух). Она задерживает дыхание, и всплывает пятая стихия - камень - символ смерти и мертвой природы:

(20) Больше не дышу. / Времечко осадное, / То, сыпняк в Москве! / Кончено. Отстрадано / В каменном мешке / Легкого! (Поэма Воздуха).

Сгущение воздуха вызывает тягость в дыхании: в Москве тиф, унесший тысячи жизней. Каменный мешок легкого - это Москва, когда-то белокаменная: отсюда смена символов - от красоты и величия до болезни и безобразия. Вырваться из каменного плена больной Москвы означает «вдохнуть свежего чистого воздуха»:

(21) Сняты врата / Воздуха. Оседлости / Прорвана черта (Поэма Воздуха).

Набрать полные легкие воздуха означает «подняться на высоту, над землей»:

(22) Твердь, стелись под лодкою/ Леткою-упла! / Но- сплошное легкое - Сам - зачем петля / Мертвая? Полощется... / Плещется... (Поэма Воздуха).

Символика второго дыхания как появления новых сил в «Поэме Воздуха» отсутствует - сил нет, как нет и дыхания:

(23) Солнцепричастная, больше не щурюсь, / Дух: не дышу уж! / Твердое тело есть мертвое тело: / Оттяготела (Поэма Воздуха).

Твердь - это и земля, и омертвевшее тело (Твердое тело есть мертвое тело). Прах от праха - вновь библейская тема в цветаевской поэме, но только в авторском изложении. 


\section{МАТЕРИАЛЫ И СООБЩЕНИЯ}

Оживление и возрождение человека происходит через движение ввысь:

(24) Танец - / Ввысь! Таков от клиник / Путь... (Поэма Воздуха).

Земля утратила свое притяжение:

(25) ...Сперва не тянет / Персть, потом не примет / Ног (Поэма Воздуха).

В церковнославянском языке персть - это «пепел, прах, грязь, земля, пыль» (Краткий церковнославянский словарь). Воздух оказывается тверже льда (Без дна, а тве́рже льдов!). Воздух может сменить землю - традиционное место обитания человека:

(26) Закон отсутствий / Bcex: сперва не держит / Твердь, потом не пустит / В вес (Поэма Воздуха).

Меняется ли от этого суть человека? Нет:

(27) Наяда? Пэри? / Баба с огорода! (Поэма Воздуха).

Сходное ощущение от полета в воздухе возникает у человека при плавании в воде:

(28) Старая потеря / Тела через воду / (Водосомущения / Плеск. Песчаный спуск...) / - Землеотпущение (Поэма Воздуха).

Полет позволяет человеку оторваться от всего земного, мирского - того, что его тяготит.

Не каждое поколение людей рождается для созидания:

(29) В ломо́ту / Жатв- зачем рождаем? / ...Всем неумолотом, / Всем неурожаем / Верха... По расщелинам / Сим - ни вол ни плуг. / - Землеотлучение: / Пятый воздух - звук (Поэма Воздуха).

По-цветаевски войны - это жертвоприношение смерти, которая забирает целые поколения живущих на земле (Землеотлучение), она их косит.

Свою жатву собирает смерть. В русской лингвокультуре смерть рисуется в виде старухи с косой - она жница, земледелица. Отсюда у М. Цветаевой появляется метафора жатвы и звука скошенной травы - не колосьев (потому что неурожай, неумолот).
Надорванные силы не позволяют человеку жить дальше:

(30) Дыра бездонная / Легкого, пораженного / Вечностью... / Не все́ ее - / Так. Иные- смерть. / - Землеотсечение. / Кончен воздух. Твердь (Поэма Воздуха).

Старуха с косой сечет нить жизни - отсекает колос от корня, и человек перестает дышать. Поэтому в «Поэме Воздуха» после землеотсечения нет четвертого вдоха (Кончен воздух). Душа оказывается на небесах. У М. Цветаевой небеса называются твердью. Твердь, по Библии, - это и есть небо (твердь небесная).

По-цветаевски отсечение голов - это не метафора семян, брошенных в землю, которая в войну не почва, не пашня, а грунт:

(31) Голов бестормозных - / Трахт! И как отсечь: / Полная оторванность / Темени от плеч - / Сброшенных! Беспочвенных - / Грунт! Гермессвои! / Полное и точное / Чувство головы / С крыльями (Поэма Воздуха).

Немецкое Tracht-«костюм». Тело - это одежда души. Душа облекается в плоть при рождении, а плоть - это платье. Чтобы освободиться и обрести крылья, душе необходимо сбросить платье. Появление имени Гермеса в этом контексте неслучайно. Древнегреческий бог Гермес считался проводником душ. Он изображался с крыльями на голове или на шлеме, надетом на голову.

Переход стихий друг в друга у М. Цветаевой обусловлен пересечением границ двух миров - этого (земного) и иного (небесного или подземного: в землю хоронят ушедших, а душа отправляется на небо). Смерть касается и тех, кто остался жить. Прикосновение смерти испытывают те люди, кто был близок умершему. Признаки этого заметны в вещественных метафорах льда: лед - мертвая вода, а тело человека - прах от праха:

(32) Уж наши руки стали льдом (Чародей).

Земля, по мысли древних, стоит на трех китах. У М. Цветаевой земля зиждется на гнилом китовом основании:

(33) Наш мир - до призрачности зыбкий / На трех своих гнилых китах... (Чародей). 
Живой человек, прикоснувшийся к смерти, замирает. Поэтесса использует образ камня. В русской лингвокультуре камень относится к первостихиям, при этом камень символизирует смерть, остановку жизни:

(34) Окаменев - тупо - гляжу, / Как моя жизнь - тонет (На красном коне).

V. В русской лингвокультуре символика земли сложна и многогранна. В мифологической традиции земля тесно связана с небом, о чем свидетельствует символика дохристианская - миф о браке неба и земли (подробнее об этом см.: [Дутбаева, 2019, с. 10961097]), с образом Великой Богини-Матери (мать сыра земля, земля-матушка), христианская, связанная с мифом о сотворении человека из праха земного (прах от праха), античная и древнеегипетская (ср. имена древнегреческой богини $Г е и$, древнеримской богини Teppbl, древнеегипетского бога Геба, корень которых содержит семантический компонент 'земля').

VI. Как и во многих древних культурах, цветаевский мир трехчастен: «небесная земля» ${ }^{4}$, «земная земля» и «подземная земля». Для подробного изучения реализации этой структуры в поэмах мы обращались к фактам биографии поэтессы, изложенным в работах исследователей [Саакянц, 1997; Стенина, 2004; Фейлер, 1998; Швейцер, 1992; 2002; Шевеленко, 2015], а также в воспоминаниях ее дочери (Эфрон, 1998).

Первая составляющая вертикали - «небесная земля». Дохристианская мифология донесла до нас понятие духов. В русской лингвокультуре существуют дух дома (домовой), духипредки (мать сыра земля) и т. Д. Духи обитают в иномирии, не на этой земле, как живые люди. Иномирие для людей кажется пустыней, потому что человеку не дано видеть духов:

(35) В безлюдии каких пустынь... (Чародей).

Иномирие начинается в горах. У горы могут быть духи-покровители-охранители:

(36) Мужайся, отрок! - Дух Горы / Один - нас двое. / Здесь только зори да орлы, / Да мы с тобою (На красном коне).
Гора во многих лингвокультурах видится медиатором между небом и землей. Для М. Цветаевой гора тоже медиатор, к ней отправляется человек, чтобы быть ближе к небу, к Богу. На горе есть возможность быть услышанной Богом:

(37) Черной ни днесь, ни впредь / Не заткну дыры. / Дай мне о го́ре спеть / На верху горы (Поэма Горы).

Ландшафт, по М. Цветаевой, имеет свои сакральные смыслы. Гора - часть земли, но она возвышается над землей, вознося человека на вершины, позволяющие ему коснуться небес. Гора, писала поэтесса, - это «верх земли и низ неба. Гора - в небе» (Пастернак Борис, Цветаева Марина. Чрез лихолетие эпохи... ).

Горы по-особому видятся М.И. Цветаевой. В «Поэме Горы» в ее ранней редакции были строки, которые не вошли в окончательный вариант:

(38) Та гора хотела! Песнь / Брачная - из ямы Лазаревой! / Та гора вопила: - Есмь! / Та гора любить приказывала... / Та гора была - миры! / Господи! Ответа требую! / Горе началось с горы. / И гора и горе - пребыли (Поэма Горы).

Гора, о которой говорится в поэме, - это Петршин-холм в Праге. Марина Ивановна дала ей свое название - Смиховский холм. Это имя произошло от района Смихов, в котором поэтесса жила осенью 1923 года. С горой связаны романтические воспоминания (Ta гора любить приказывала). Горы символизируют любовь - разделенную, страстную, пылкую. Эта гора принесла Марине Цветаевой горе (Горе началось с горы).

Гора своим подножием упирается в землю - там ее основание. У поэтессы основание горы - в смертной яме (из ямы Лазаревой). Вершина горы в небесах, в облаках. Сама гора теоморфна (гора вопила: - Eсмь!). Библейское имя бога Яхве переводится «Я есть» - аллюзия на текст Библии. В произведениях М.И. Цветаевой гора - объемна, огромна, ее вершина символизирует высоту духа, ее образ ассоциируется с лавиной чувств. Гора знаменует величие любящего человека.

Вторая составляющая вертикали - «земная земля». В мифологии это срединный мир ${ }^{5}$. Земля - это место, где живет человек. Это 
первичный признак земли, который часто встречается в цветаевских контекстах:

(39) Не мудрено: на земле живут, / Не в облаках витают (Крысолов).

Выражение жить на земле означает не просто «место обитания», но и «быт», «уклад», «устои». Ему противопоставляется выражение витать в облаках, означающее «грезить, мечтать», - таким выражением характеризуется жизнь поэтов и людей не от мира сего.

Уже упоминавшееся выражение соль земли поэтесса заменяет на авторское выражение кровь земли, вводя эту соматическую метафору в контекст признаков, носителями которых являются талантливые люди и творцы истории:

(40) Наша кровь - та же смоль! / Раз кровь кровью смой! / Пусть ропщут умы, - / Все ж кровь земли - мы! (Крысолов).

Однако общий смысл не возвышенный, в этом выражении скрыта ирония, являющаяся вершиной развития концептуальной структуры. Ирония десакрализирует, обесценивает то, что было некогда сакральным. На это указывает метафора падения, выражающая негативную оценку: пасть ниже земли означает «падение ниже возможного уровня; утрата авторитета»:

(41) Наша дробь - та же трель! / - Эй, раб! Влево цель! / Пав ниже земли, - / Все ж цвет ее... / - Говорю вам: не те холмы! (Крысолов).

Цвет, расцвет, цветение - символ весны, оживления природы, рост и благосостояние. Падение в этом контексте нивелирует эти смыслы. Горы, так высоко ценимые поэтессой, превращаются у нее в холмы - недогоры.

Бытие в этом мире определяется двумя цветаевскими образами: дома и нити, имеющими глубинные смыслы. Дом человек строит на земле, утверждая основу своей жизни в этом мире. Нить символизирует земные отношения между людьми. В русской лингвокультуре метафорами нити реализуются признаки родства (наши судьбы переплелись, узы брака, родственная связь и т. п.). Рассмотрим эти образы в анализируемых цветаевских поэмах.
Дом - мифологема, известная практически всем народам. Выражение жить на земле представляет стертую доместическую метафору, которая встречается в изучаемой авторской картине мира:

(42) Не мудрено: на земле живут, / Не в облаках витают (Крысолов).

Религиозное сознание христиан отождествляет человека с домом. В тексте Библии используется метафора дома в описании человека: «ибо кто из человеков знает, что в человеке, кроме духа человеческого, живущего в нем?» (1 Коринф., 2:11). По словам Г. Гачева, «дом - макет мироздания, национальный Космос в миниатюре. Здесь земля (пол), небо (крыша), страны света (стены) и т. д. Как мир, природа - храм, дом Бога, так дом - храм человека; человек творит дом, как Бог мир о по своему образу и подобию. Как в нашем теле заключена душа и просвечивает сквозь тело, так дом - тело на нас; человек во плоти - как душа в доме» [Гачев, 1995, с. 38].

Сложные жизненные обстоятельства, потеря родного дома и Родины оставили отпечаток на творчестве поэтессы. Земля в авторской картине мира выполняет основную функцию дома - защитную:

(43) Греши с Богом! / Земля скроет! / Под порогом / Яму роют (Молодец).

Символика земли-дома передается в произведениях М.И. Цветаевой ${ }^{6}$ через когнитивные признаки частей дома - 'пол':

(44) В час? Трава не росла бы в дом - / Пол, земля не вошла бы в дом (Попытка комнаты);

признаки домашнего быта - 'ковер’:

(45) До ковровой до земли склонилась истово, / Об царевы сапоги звенит монистами (Царь-девица).

Доместическая метафора земли преломляется у М.И. Цветаевой сквозь христианскую мифологему «земля - место вечного упокоения / могила»:

(46) В землю пальчиком гусляр: «Вечный дом! - / Ты в супружестве живешь во втором» (Царь-девица). 
Земля защищает человека, но не в этой жизни, а после его ухода из этого мира.

Дом в огне у М.И. Цветаевой - это символ Родины, символ покинутой земли. Родина - это стертая метафора Великой Богини-Матери и ее славянской ипостаси матери сырой земли. Земля из пашни, цветущего сада превращается в прах и тлен, золу и шлак:

(47) Где ж шлак? / Весь - золой / Лак, лак / Локтевой! (Поэма лестницы).

Еще один образ дома - уголь и огонь:

(48) Час пахнет бомбою. / Ве - ревка: льном была! / Огнь, в куче угольной: / - Был бог и буду им! (Поэма лестницы).

Дом и родная земля для М.И. Цветаевой одно и то же, это неразрывные понятия, концептуально сближенные для всех носителей русского языка.

Дохристианский символ матери сырой земли скрыт у М.И. Цветаевой в признаках пашни. Тела солдат, павших на поле сражения, уходят в землю, как семена:

(49) Солдаты! До неба - один шаг: / Законом зерна́ - в землю! (На красном коне).

Жизнь циклична. Родился человек из лона матери и уходит после своей смерти в лоно земли.

Упомянутая выше метафора нити жизни понимается М. Цветаевой своеобразно море, символизирующее для поэтессы смерть, связано с землей, от которой человек тоже не получает защиты:

(50) Шов, а не перевязь, шов - не щит. / - O, не проси защиты! - / Шов, коим мертвый к земле пришит, / Коим к тебе пришита (Поэма Конца).

Связь земли и человека в русской лингвокультуре представлена терминами родства - земля-матушка. Перестав быть плодородной - родной, земля предстает глиной жидкой, когда разверзлись хляби небесные и мир погрузился в хаос:

(51) Сапогом судьбы, / Слышишь - по глине жидкой? (Поэма Конца).
В 1921 г. пишется поэма «На красном коне», где звучат такие строки:

(52) Не Муза, не Муза, - не бренные узы / Родства, - не твои путы, / О Дружба! - Не женской рукой, - лютой, / Затянут на мне - / Узел (На красном коне).

Параллельно с традиционными для русской лингвокультуры смыслами родственных yз, nym, затрудняющих движение вперед, мы встречаем авторские эпитеты: узы родства бренные, путы Музы, петля, затянутая лютой, не женской рукой, - узел. Нити, соединяющие людей в этом мире, не продолжают канву узора ткани жизни, а, завязываясь в узел, завершают этап творения-творчества, знаменуют переход в иной мир.

В произведениях М. Цветаевой часто обыгрываются пересекающиеся мыслеобразы: Море - морская - Марина. Первоначально море для поэтессы - это неведомая земля, познание которой даст возможность обретения внутренней целостности:

(53) - Свидимся - не знаю, но - споемся! / С мне-самой неведомой землею - / С целым морем, Райнер, с целой мною! (Новогоднее).

Самопознание начинается с самоидентификации - с имени.

Позже М.И. Цветаева стала противопоставлять горам море, которое она невзлюбила. В творческом наследии поэтессы символы горы и моря приобрели полярный смысл. В своем письме Борису Пастернаку от 25 мая 1926 г. она пишет: «Есть вещи, от которых я в постоянном состоянии отречения: море, любовь. Океан, как монарх, как алмаз: слышит только того, кто его не поет. А горы благодарны (божественны)» (Пастернак Борис, Цветаева Марина. Чрез лихолетие эпохи... ).

Земля, Россия, Родина - равноположенные символы русской лингвокультуры, мир родных и близких людей - для поэтессы имеют особый цвет:

(54) Сын голубейшей из отчизн! (Чародей).

Голубой - цвет воды и неба. Небо отражается в воде и символизирует свободу, ширь, отсутствие границ. Мир Отчизны после революции окрашивается в другой цвет - цвет 


\section{МАТЕРИАЛЫ И СООБЩЕНИЯ}

крови. Красный цвет обретает значение жертвенности. На предстоящую смерть указывают знамения - знаки с небес, встает необычной формы алая - кровавая - заря:

(55) Разломано небо! - Благой знак: / Заря кровянит шлем мой! (На красном коне).

Красный цвет - это и цвет пожара, в котором сгорел родной дом:

(56) Грязь явственно сожжена! / Дом - красная бузина! (Поэма лестницы).

Огонь обретает смысл очищения от грязи, скверны, греха. Вот только сожженный дом не будет заново отстроен и заселен. Сгоревший дом - умерший. Люди, жившие в этом доме, тоже как будто умирают:

(57) Есть взамен пожизненной / Смерти жизнь посмертная! (Поэма лестницы).

Где строить новый дом, если вся Родина в революционном огне? Где скитальцам, покинувшим родную землю, строить свой дом, если земля - чужая?

Третья составляющая вертикали - «земля подземная» ${ }^{7}$. Христианская составляющая русской лингвокультуры характеризуется такими признаками подземной земли, как 'прах' и 'могила'.

В поэме «Чародей», написанной в 1914 г., важным символом земли для поэтессы становятся похороны. Мать Марины Ивановны Цветаевой - Мария Александровна Мейн - ушла из жизни в 1906 г., когда дочери было 14 лет. Земля для поэтессы в этот период представляется не цветущим садом, а могилой матери:

(58) Мать под землей, отец в Каире... / Еще какое-то пятно! / Уже ничто смешное в мире / Нам не смешно (Чародей).

Смерть близких заставляет по-взрослому взглянуть на мир и свою жизнь. Из-под ног детей ушла земля, которая всегда была опорой, символом незыблемости и нерушимости мира: родей).
Земля - символ опоры, устойчивости (крепко стоять на земле) - меняется. В жизни молодой поэтессы все изменилось: исчезла стабильность, четкость видения, появились призрачность и иллюзорность из-за непонимания своего будущего, мешающие твердо стоять на ногах. Переход в другой мир - мир, из которого сначала уходит мать, самый близкий и дорогой человек, а потом уходит и Родина, родная земля-матушка, - описывается поэтессой метафорами сотрясания, вала и моста. При этом мост и вал несут в себе символику перехода, границы между мирами:

(60) Мост ли дрожит, я ли - дрожу? (На красном коне);

крови и стона: коне).

(61) Кровь или вал - стонет? (На красном

Метафора землетрясения будет и позже использоваться М.И. Цветаевой для описания душевного потрясения, скорби, сердечных переживаний, скрываемых от окружающих:

(62) Рассказать, как про твою узнала? / Не землетрясенье, не лавина. / Человек вошел - любой (любимый - / Ты). - Прискорбнейшее из событий. / - В Новостях и в Днях (Новогоднее).

Исчезновение из этого мира в русской лингвокультуре осмысляется как достижение конца пути. Дорога - это жизненный путь (традиционная для русского языка метафора). Прошедший свой жизненный путь уже не оставляет следы на земле, его следы остывают: родей).

(63) Вы... / Чьей матери остыл и след... (Ча-

Мир сестер Цветаевых после ухода матери превратился в бездну невысказанных слов:

(64) Вы, в ком поет, // И жалуется, и томится / Вся несказанная земля! / Вы, розы, вы, ручьи, вы, птицы, / Вы, тополя - // Вы, мертвых Лазарей из гроба / Толкающие в зелень лип, / Вы, без кого давным-давно бы / Уже погиб (Чародей).

Можно ли дочерям повторить чудо Иисуса Христа, поднявшего мертвого Лазаря на чет- 
вертый день из гроба, воскресившего его к новой жизни? О похороненной матери томится сердце и душа ее детей. Много-много раз символизм утраты будет возникать в творчестве поэтессы.

Символизм ухода из жизни читается в признаках Сорокоуста - когда сорок дней после смерти в молитвах поминаются ушедшие на тот свет:

(65) Как рокот Сорокоуста / Метель взмелась: / Престол опрокинут! - Пусто! / Как в землю сгас! (На красном коне).

Душа, горящая в груди человека как искра божия, гасится после похорон. Традиционно в русской лингвокультуре считалось, что тело уходит в землю (где покоится с миром) как тлен, а душа уносится к Богу там ее родина. Однако у М. Цветаевой мы встречаем иной взгляд: душа гасится вместе с похороненным телом (сzас).

Концептуализация земли как могилы, знаменующей уход в мир иной - подземный, реализуется в цветаевских поэмах посредством когнитивных признаков 'рва', 'захоронения', 'смерти', 'прихода гения / тени за душой умершего'. Одним из способов актуализации является выражение чернота рва, которое отсылает читателя к образу могилы, общей для коллективно похороненных в ней людей:

(66) Сей страшен союз. - В черноте рва / Лежу а Восход светел. / О, кто невесомых моих два / Крыла за плечом - / Взвесил? (На красном коне).

Цветаевское описание смерти как ухода в подземный мир отражает философское ее восприятие: через дихотомию образов и краткость языковых форм достигается сложнейший смысл сосуществования тьмы и света-смерти и жизни (чернота - рва, восход-светел), бренности тела и божественной сути человека (за плечом - два крыла невесомых).

Поэтесса пишет:

(67) Немой соглядатай / Живых бурь - / Лежу - и слежу // Тени. Доколе меня / Не умчит в лазурь / На красном коне - / Мой Гений! (На красном коне).

М. Цветаева продолжает авторский смысловой ряд. Символы смерти - немота и тени: умершие при переходе из этого мира в иной не могут говорить, но еще могут видеть живых (Немой соглядатай живых бурь) и уже могут видеть мертвых (слежу тени), духи умерших называются тенями. Умерший обездвижен (лежу), его способы восприятия ограничены (слежу). Состояние перехода из одного мира в другой имеет предел: его завершает приход гения - духа-покровителя из древнеримской мифологии. Он забирает душу умершего и уносит его на красном коне на небо (умчит в лазурь).

VII. Авторское видение получают в произведениях М. Цветаевой разные мифологические и религиозные мотивы, связанные с землей. Известный миф об Атланте, держащем на своих плечах небесный свод, чтобы он не рухнул на землю и не уничтожил на ней жизнь, в «Поэме Горы» описывается поэтессой иначе. На это указывают авторские когнитивные признаки горы в цветаевских контекстах. Гора - это горб на спине Атланта:

(68) Та гора была, как горб / Атласа, титана стонущего (Поэма Горы).

Горба люди обычно стыдятся. Однако горами принято гордиться:

(69) Той горою будет горд / Город, где с утра и до́ ночи мы // Жизнь свою - как карту бьем! (Поэма Горы).

Каждый из нас несет не свой крест, как Иисус в Библии, а имеет свою ношу - гору на плечах:

(70)Вздрогнешь-и горы с плеч, / Идуша-горе́. / Дай мне о горе́ спеть: / О моей горе́! (Поэма Горы).

Посредством выражения душа - горе́ поэтесса отсылает к церковнославянскому возвести очи горе́ со значением «поднять глаза вверх». Душа - горе́ означает в данном случае «душа в небо». В этом же контексте выражение Вздрогнешь - $и$ горы с плеч сама М.И. Цветаева поясняет дальше так:

(71) Горе началось с горы. / Та гора на мне надгробием (Поэма Горы),

то есть вместо этого камня (горы на мне) будет плоский (плита). Гора - это камень. 


\section{МАТЕРИАЛЫ И СООБЩЕНИЯ}

А камень - символ смерти. На могиле в России по традиции ставят камень.

В произведении М.И. Цветаевой гора описывается соматической метафорой, скрывающей в себе миф о жертве небу:

(72) Хрип - и громоподобный ре́в / Грудь горную рассек. / Как Первенца его воздев, / Встает как сам Набег (На красном коне).

В скандинавской мифологии встречается мотив принесения в жертву первочеловека Имира, из тела которого был создан весь мир - земля и небесные объекты. В славянской мифологии есть похожий миф о сотворении мира из частей Бога, рассказанный в Голубиной книге: «В дохристианской (славянской, скандинавской) концепции утверждалось, что сотворение мира происходило путем жертвоприношения, когда каждая частица жертвы была основой для создания явлений мира Бог, или Первочеловек, “растворился” в мире» (цит. по: [Пименова, 2007, с. 235]). Однако у М.И. Цветаевой мы встречаем авторское видение мифа о сотворении мира.

Оппозиции «гора - земля» М.И. Цветаева противопоставляет свою: «гора - море». Море концептуализируется признаками смерти, которые актуализируются метафорами жерновов:

(73) Мельня ты мельня, морское коло! / Мамонта, бабочку, - все смололо / Море. О нем щепоть / Праха - не нам молоть! (С моря).

То, что остается после всего живого - это прах. Прах от праха - метафора сотворенного человека, взятая из Библии, - у М.И. Цветаевой расширяется до представления о всем живом (Мамонта, бабочку). Метафора круга жизни как мельницы, жернова которой производят муку́ - му́ку, часто встречаемая в русской поэзии, у поэтессы реализует иные смыслы. Круг жизни - это морское коло, мельница - это море (Мельня ты мельня... / ...все смололо / Море). Сопоставим размеры человека и Бога, если для сотворения человека нужна всего щепоть праха. О круге жизни - смерти человек судить не может (не нам молоть!). Этот контекст включает стертые метафоры: Бог - это и мельник (...морское коло! / Мамонта, бабочку, - все смололо... / ...не нам молоть!), и кузнец (глагол молоть и суще- ствительное молот этимологически родственны).

У поэтессы отмечено еще несколько символов земли, характерных для русской лингвокультуры. Выражение глаза долу - в землю - символизирует скромность:

(74) А глаза почему у них / В землю? Во-первых-скромность... (Крысолов).

Вероятно, мы встречаемся с христианским пониманием правильного поведения человека в этом мире (глаза долу, душа горе́).

Земля и небо - оппозиция вертикального пространства. Земля символизирует естественную пространственную точку самого низа. Осесть до земли означает «низко присесть»:

(75) - В Москву! - В Карлсбад! / - У меня оседает зад. / -У меня, по уграм, прострел. / - У меня - так совсем осел / До земли... (Крысолов).

После отъезда поэтессы с Родины происходит ее знакомство с иной культурой. У символа земли появляются когнитивные признаки государственности, места обитания и сопутствующие им ассоциативные признаки:

(76) - Ти-ри-ли - / -По рассадам германской земли, / - Ти-ри-рам - / По ее городам / - Красотой ни один не оставлен - // Прохожу, / Госпожу свою Музыку - славлю (Крысолов); - Грету? Не Греты у нас и нет: / В землях живем германских. / В городе Гаммельне столько ж Грет, / Сколько, к примеру, Гансов (Крысолов).

Поэтическое наследие М.И. Цветаевой в аспекте мифов и символов родной культуры требует дальнейшего своего осмысления.

\section{Выводы}

Символизм земли у Марины Ивановны Цветаевой напоминает древнюю традицию «плетения словес» [Зубова, 1985], понимать которые могли только знающие - осознающие. Анализ макроконцепта «земля» посредством выявления концептуальных символических признаков позволил раскрыть смыслы, скрытые в переплетенных сюжетных линиях цветаевских поэм. 
М. Цветаева использует образы из разных мифологий: славянской (Даждьбог - из частей его тела образован мир), скандинавской (Имир - первочеловек, принесенный в жертву богами ради создания мира-земли), древнегреческой (Атлант, держащий на своем горбу-горе небо). Образ Бога у М. Цветаевой восходит не к Библии, где используется гончарная метафора сотворения человека из глины / праха земного: он - великан, мельник и кузнец.

Символы земли у М. Цветаевой можно разделить на 2 блока:

- традиционные для русской лингвокультуры символь, в которые вошли как дохристианские (включая древнерусские и скандинавские), так и христианские символы: 1. Земля - место обитания, проживания (голубая Отчизна, дом, семья). 2. Земля - опора, символ незыблемости и нерушимости мира (твердыня). 3. Земля - нижняя точка пространственной вертикали (соотносимая с первой частью оппозиций: земля - небо, земля / человек - бог). 4. Земля - христианский символ скромности. 5. Земля - символ смерти / праха / тлена. 6. Соль земли - символ талантливых, одаренных людей;

-индивидуально-авторские поэтические символы: 1. Земля - скала / камень. 2. Земля - гора. 3. (Неведомая) земля - море. 4. (Новая) земля - воздух. 5. Кровь земли талантливые, одаренные люди / жертва.

Указанные символы связаны с мифами и традициями христианского поведения, ритуальной практикой похорон, категориями культуры (пространственной вертикалью, цветовым спектром, а также бытом, укладом, устоями, ритуалами). Символом мира на земле у М. Цветаевой является голубой цвет мирного неба и воды. Красный цвет выступает символом огня, революционного пожара, горящего дома и покидаемой родной земли.

Метафора нити, широко используемая в русской лингвокультуре, выражает утраченные знания о Великой Богине-Матери - ее образ читается в мифологеме мать сыра земля. Великая Богиня-Мать - Великая Пряха, ткущая ткань судьбы своих детей - своего народа. У М. Цветаевой метафора нити переосмысляется: муза-вдохновительница поэтессы связывает ее путами; брачные узы и узы род- ства - временные, бренные; узел-петля, наброшенная на шею женщины, затянута не женской (а чьей?) лютой рукой, следовательно, и смерть с косой - традиционный для русской лингвокультуры образ смерти - у М. Цветаевой не наш, чужой (лютым русские называют врага, беса); творчество прекращается завязыванием конечного узла в канве жизни.

Авторские воззрения на душу человека у М. Цветаевой тоже своеобразны. Тело после смерти уходит в землю, как прах от праха, и огонь - искра души - гасится при захоронении тела. Душа - не бессмертна? Огонь души гасит земля. Из земли первочеловек создан, в землю каждый рожденный человек уйдет.

\section{ПРИМЕЧАНИЯ}

${ }^{1}$ Символ земли-матери широко представлен в стихотворениях М. Цветаевой признаками 'рождение': А в этот же час, на земле этой самой / Небесную музыку слушают дамы / В иелках и напитки небеснье тянут / Из рюмок... Ответную музыку даме: / - За винтиком винтик, шуруп за шурупом, - / Скрываем за стиснутыми зубами. <..> / Mы, женщины, сльшим родящую землю! Мы, женщчины, помним о собственном лоне! (Песня о работнице) - и 'кормление': От сладостей земных Мечта еще жесточе! / Мечта, извечный дуб, питаемый землей! / Чем выше ты растешь, тем ты страстнее хочешь / Достигнуть до небес с их солнцем и луной (Плаванье). Символизм земли-матери реализуются посредством гендерными метафор родства: И несколько умов, любовников Безумья, / Решивших сократить докучный жизни день / Ив опия морей нырнувших без раздумья, - / Вот Матери́-Земли извечный бюллетень! (Плаванье). У М. Цветаевой люди - это дети Земли: Блаженны дочерей твоих, Земля, / Бросавшие для боя и для бега. / Блаженны в Елисейские поля / Вступившие, не обольстившись негой (Хвала Афродите); Яувидал монахинь бледных, / Земли отверженных детей, / И в их молитвах заповедных / Я уловил пожар страстей (В Кремле).

${ }^{2}$ Богатырь - надежда и опора земли русской силы свои берет от нее: Лежит ничком наглеи, / Прах-землю лопает. / Что в ледоход гребеи, / Плечьми работает (Егорушка).

${ }^{3}$ Цветаевская земля, являясь одной из первостихий (огонь, вода, воздух, земля), в стихотворениях переосмысляется в категориях других стихий, например огня: И вот исчез, в черную ночь исчез, / - Как некогда Иосиф, плаш свой бросив. / Гляжу 


\section{МАТЕРИАЛЫ И СООБЩЕНИЯ}

на плащ - черного блеска плащ, / Земля (горит), а сердие - смерти просит (И вот исчез, в черную ночь исчез...); Елисейские Поля: ты да я. / И под нами - огневая земля (Елисейские Поля: ты да я...) или воздуха / ветра: Может, туча из недр морских вынесет на горизонт / Эту землю-как бурю, задержанную в полете (Горизонт).

${ }^{4} \mathrm{~B}$ стихотворениях наблюдается прямая связь между небом и землей: Стою на искрящейся травке, / Под небом, пахнущем землей (Мельница); Меж нами не версты / Земные, - разлуки / Небесные реки, лазурные Земли, / Где друг мой навеки уже - / Неотъемлем (Все круче, все круче...); - Насмарку твой стих! / На стройку твой лес / Столетний! / - Не верь, сын! / И вместо земных / Насильных небес-/ Небесных земель / Синь (Насмарку твой стих!..).

${ }^{5}$ В стихотворениях представление о среднем мире, где живут люди, относят к древнему мифу о земле плоской формы, у которой есть края: С тенями по самый край // Земли. / Всю, всю покроем / Телами - вслед теням! / Делами! Полк - покоем (Выход).

${ }^{6}$ В стихотворениях этот список дополняется признаком домашнего быта 'кровать': Нам бессонниияа не бремя, / Отродясь кипим в котле. / Так-то лучше. Будет время / Телу выспаться в Земле (Поздний свет тебя тревожит?..); признаком традиций русского народа 'гостеприимство': $A$ этот колокол там, что кремлевских тяже́ле, / Безостановочно ходит и ходит в груди, - / Это - кто знает? - не знаю, - быть может, - должно быть - / Мне загоститься не дать на российской земле! (Руки даны мне - протягивать каждому обе...); признаком покидания дома-земли: Отступились сердиа от меня! / Отвернулись друзья и родня! / Onyстела живому земля... / Иль боятся те люди меня? (Отступились сердца от меня!..); На этой земле я невольный жилец, / Зато самовольно ее не оставлю! / Единственный долг мой - прожить как боеи / Имир целовать огневыми устами (Исповедь).

${ }^{7}$ Подземный мир в русской лингвокультуре представляет собой некое вместилище с соответствующими дименсиональными и категориальными характеристиками: глубина земли, дно земли, опустить в землю, уйти в землю, под землей и т. д. Все когнитивные признаки «подземной земли» в стихотворениях М. Цветаевой ассоциируются со смертью: Только этим и страшна мне / Смерть, глубокая земля, / Что под камнем не сльшна мне / Будет песня соловья (Этери); Ипадает шелковый пояс / К ногам его - райской змеей... / А мне говорят - успокоюсь / Когда-нибудь, там, под землей (И падает шелковый пояс...); Уж ветер стелется, уже земля в росе, / Уж скоро звездная в небе застынет вьюга, / Ипод землею скоро уснем мы все, /
Кто на земле не давали уснуть друг другу (Я знаю правду! Все прежние правды - прочь!..) - или Деревом Мировым: С листвы молодой игрой / Над бровью, с живой корой, / С слезами живой смолы, / С корнями до дна земли! (Мой письменный верный стол...).

\section{СПИСОК ЛИТЕРАТУРЫ}

Александров В. Ю., 1983. Фольклорно-песенные мотивы в лирике Марины Цветаевой // Русская литература и фольклорная традиция : сб. науч. тр. / отв. ред. Д. Н. Медриш. Волгоград : Изд-во ВГПИ. С. 103-112.

Афанасьева Н. А., Шишкина О. Ю., 2002. Мифологема и архетип в языковой модели мира М. Цветаевой // На путях к постижению М. Цветаевой : сб. докл. ІХЦветаевской Междунар. науч.темат. конф. (г. Москва, 9-12 окт. 2001 г.). М. : Дом-музей М. Цветаевой. С. 378-385.

Бабенко И. И., 2000. Семантические преобразования лексемы вероломство в поэтических текстах М.И. Цветаевой // Коммуникативнопрагматические аспекты слова в художественном тексте / под ред. Н. С. Болотновой. Томск : ЦНТИ, 2000. С. 125-132.

Безменова С. А., 1985. Поэма М. Цветаевой «На красном коне»: (к проблеме жанра) // Художественное творчество и литературный процесс. Томск : Изд-во Том. ун-та. Вып. 7. C. 114-126.

Береговская Э. М., 1998. Синтаксические фигуры в лирике Марины Цветаевой // Речевое общение : (Теоретические и прикладные аспекты речевого общения). Вып. 7. С. 56-64.

Беспалова О. Е., 2002. Концептосфера поэзии Н.С. Гумилева в ее лексическом представлении : автореф. дис. ... канд. филол. наук. СПб. 24 с.

Бобров А. А., 2008. Серебряный век Подмосковья. М. : Алгоритм. 320 c.

Боровикова М., 2007. Литературная биография Цветаевой: полемический аспект // Русская филология : сб. науч. работ молодых филологов. Тарту: Тартуский ун-т. Вып. 18. С. 73-78.

Вахтель Н. М., 2002. Стилистические фигуры в поэзии Марины Цветаевой // Вестник Воронежского государственного университета. Серия: Гуманитарные науки. № 1. С. 28-41.

Волкова Е. В., 2018. Эволюция концепта ФРАНЦИЯ в индивидуально-авторской картине мира М.И. Цветаевой: 1910-1920 годы // Новое в лингвистике и методике преподавания иностранных и русского языков : сб. науч. ст. / под общ. ред. М. В. Пименовой. СПб. : Изд-во СПбГЭУ. С. 263-268. 
Гачев Г. Д., 1995. Национальные образы мира. Космо - Психо - Логос. М. : Прогресс : Культура. $480 \mathrm{c}$.

Головей М. Г., 2011. Музыка в бытийном пространстве М.И. Цветаевой и А.И. Цветаевой // Вестник Тверского государственного университета. Серия «Филология». № 3. С. 177-180.

Голубиная книга: Русские народ. духовные стихи XI-XIX вв., 1991 / сост. вступит. ст. примеч. Л. Ф. Солощенко, Ю. С. Прокошина. - М. : Моск. рабочий. -351 с.

Дутбаева С. С., 2019. Лингвокультурологические особенности образов небесного мира в русской поэзии 90-х годов XX века // Вестник Кемеровского государственного университета. Т. 21, № 4. С. 1095-1104.

Зубова Л. В., 1985. Традиции стиля «плетение словес» у Марины Цветаевой («Стихи к Блоку», 1916-1921 гг., «Ахматовой», 1916 г.) // Вестник Ленинградского государственного университета. № 9. С. 47-52.

Колесов В. В., 1992. Концепт культуры: образ - понятие - символ // Вестник Санкт-Петербургского государственного университета. Серия 2. № 2. C. 3-40.

Маслова В. А., 2000. Марина Цветаева: над временем и тяготением. Минск : Экономпресс. $224 \mathrm{c}$.

Маслова В. А., 2017. Поэт и культура: концептосфера Марины Цветаевой. М. : ФЛИНТА. $254 \mathrm{c}$.

Мошина Е. А.,2019. Мифологические параллели в метафорах земли в авторской картине мира М.И. Цветаевой // Языки и культура народов России и стран СНГ : сб. ст. / под общ. ред. М. В. Пименовой. СПб. : Изд-во СПбГЭУ. С. 91-96. (Серия «Концептуальный и лингвальный миры»; вып. 17).

Пименова М. В., 2007. Концепт сердие: образ, понятие, символ. Кемерово : КемГУ. 500 с. (Cерия «Концептуальные исследования»; вып. 9).

Пименова М. В., 2011. Символические концепты как часть концептуальной системы (на примере концепта творчество) // Когнитивная лингвистика: новые парадигмы и новые решения : сб. ст. памяти проф. Евгения Александровича Пименова / отв. ред. М. В. Пименова. М. : ИЯ РАН. С. 65-83. (Серия «Концептуальные исследования» ; вып. 15).

Пименова М. В., Волкова Е. В., 2018. Концепт Франциия в индивидуально-авторской картине мира М.И. Цветаевой // Гуманитарный вектор. Т. 13, № 1. С. 105-111.

Саакянщ А. А., 1997. Марина Цветаева. Жизнь и творчество. М. : Эллис Лак. 816 с.
Стенина Н. А., 2004. Чешское окружение М. Цветаевой // «Чужбина, родина моя!» : Эмигрантский период жизни и творчества Марины Цветаевой : сб. докл. ХІ Междунар. науч.-темат. конф. (Москва, 9-12 окт. 2003 г.). М. : Доммузей Марины Цветаевой. С. 32-41.

Фейлер Л., 1998. Марина Цветаева : пер. с англ. Ростов н/Д : Феникс. 416 с.

Швейцер В. А., 1992. Быт и Бытие Марины Цветаевой. М. : Интерпринт. 544 с.

Швейцер В. А., 2002. Марина Цветаева. М. : Молодая гвардия. $591 \mathrm{c.}$

Шевеленко И. Д., 2015. Литературный путь Цветаевой: идеология, поэтика, идентичность автора в контексте эпохи. М. : НЛО. 448 с.

\section{ИСТОЧНИКИ И СЛОВАРИ}

Краткий церковнославянский словарь. URL: https:// slovar.cc/rel/cerkov/2320927.html (дата обращения: 04.11.2019).

Пастернак Борис, Цветаева Марина. Чрез лихолетие эпохи... Письма 1922-1936 гг. URL: https://books.google.ru/books?id=q7kTDgA AQBAJ\&pg (дата обращения: 03.11.2019).

Цветаева М. И. Собрание сочинений. В 7 т. Т. 2. Стихотворения. Переводы / сост., подгот. текста и коммент. А. Саакянц, Л. Мнухина. М. : Эллис Лак, 1994. 592 с.

Цветаева М. И. Собрание сочинений. В 7 т. Т. 3. Поэмы. Драматические произведения / сост., подгот. текста и коммент. А. Саакянц, Л. Мнухина. М. : Эллис Лак, 1994. 816 с.

Цветаева М. И. Собрание сочинений. В 7 т. Т. 6. Письма / вступ. ст. А. Саакянц ; сост., подгот. текста и коммент. Л. Мнухина. М. : Эллис Лак, $1995.800 \mathrm{c}$.

Эфрон А. С., 1998. О Марине Цветаевой : Воспоминания дочери. М. : Совет. писатель. 480 с.

\section{REFERENCES}

Aleksandrov V.Yu., 1983. Folklorno-pesennye motivy v lirike Mariny Tsvetaevoy [Folklore-Song Motifs in the Lyrics of Marina Tsvetaeva]. Medrish D.N., ed. Russkaya literatura $i$ folklornaya traditsiya: sb. nauch. tr. [Russian Literature and Folklore Tradition. Collection of Scientific Works]. Volgograd, Izd-vo VGPI, pp. 103-112.

Afanasyeva N.A., Shishkina O.Yu., 2002. Mifologema i arkhetip $v$ yazykovoy modeli mira M. Tsvetaevoy [The Mythologeme and Archetype in the Language Model of the World 
of M. Tsvetaeva]. Na putyakh $k$ postizheniyu M. Tsvetaevoy: sb. dokl. IX Tsvetaevskoy Mezhdunar. nauch.-temat. konf. (Moskva, 912 okt. 2001 g.) [On the Ways to Comprehend M. Tsvetaeva. Proceedings of the $9^{\text {th }}$ Tsvetaeva International Scientific and Thematic Conference (Moscow, October 9-12, 2001)]. Moscow, Dommuzey M. Tsvetaevoy, pp. 378-385.

Babenko I.I., 2000. Semanticheskie preobrazovaniya leksemy verolomstvo $\mathrm{v}$ poeticheskikh tekstakh M.I. Tsvetaevoy [Semantic Transformations of the Lexical Unit Verolomstvo in the Poetry Texts of M.I. Tsvetaeva]. Bolotnova N.S., ed. Kommunikativno-pragmaticheskie aspekty slova $v$ khudozhestvennom tekste [CommunicativePragmatic Aspects of a Word in a Literary Text]. Tomsk, TsNTI, pp.125-132.

Bezmenova S.A., 1985. Poema M. Tsvetaevoy «Na krasnom kone»: (k probleme zhanra) [The Poem of M. Tsvetaeva "On the Red Horse": (On the Problem of the Genre)]. Khudozhestvennoe tvorchestvo i literaturnyy protsess [Artistic Creation and Literary Process]. Tomsk, Izd-vo Tomskogo universiteta, iss. 7, pp. 114-126.

Beregovskaya E.M., 1998. Sintaksicheskie figury v lirike Mariny Tsvetaevoy [Syntactic Figures in the Lyrics of Marina Tsvetaeva]. Rechevoe obshchenie: (Teoreticheskie $i$ prikladnye aspekty rechevogo obshcheniya) [Speech Communication (Theoretical and Applied Aspects of Speech Communication)], iss. 7, pp. 56-64.

Bespalova O.E., 2002. Kontseptosfera poezii N.S. Gumileva vee leksicheskom predstavlenii: avtoref. dis. ... kand. filol. nauk [Concept Sphere of N.S. Gumilev's Poetry in Its Lexical Representation. Cand. philol. sci. abs. diss.]. Saint Petersburg. 24 p.

Bobrov A. A., 2008. Serebryanyy vek Podmoskovya [Silver Age of Moscow Region]. Moscow, Algoritm Publ. $320 \mathrm{p}$.

Borovikova M., 2007. Literaturnaya biografiya Tsvetaevoy: polemicheskiy aspekt [Literary Biography of Tsvetaeva: A Polemical Aspect]. Russkaya filologiya: sb. nauch. rabot molodykh filologov [Russian Philology. Collection of Scientific Works of Young Philologists]. Tartu, Tartuskiy universitet, iss. 18, pp. 73-78.

Vakhtel N.M., 2002. Stilisticheskie figury v poezii Mariny Tsvetaevoy [Stylistic Figures in the Poetry of Marina Tsvetaeva]. Vestnik Voronezhskogo gosudarstvennogo universiteta. Seriya: Gumanitarnye nauki [Proceedings of Voronezh State University. Series: Humanities], no. 1, pp. $28-41$.

Volkova E.V., 2018. Evolyutsiya kontsepta FRANTsIYa $\mathrm{v}$ individualno-avtorskoy kartine mira M.I. Tsvetaevoy: 1910-1920 gody [The Evolution of the FRANCE Concept in the Individual Author's Picture of the World of M.I. Tsvetaeva: 1910 1920]. Pimenova M.V., ed. Novoe v lingvistike $i$ metodike prepodavaniya inostrannykh $i$ russkogo yazykov: sb. nauch. st. [New in Linguistics and Methods of Teaching Foreign and Russian Languages. Collection of Scientific Articles]. Saint Petersburg, Izd-vo SPbGEU, pp. 263-268.

Gachev G.D., 1995. Natsionalnye obrazy mira. Kosmo - Psikho - Logos [National Images of the World. Cosmo - Psycho - Logos]. Moscow, Progress Publ., Kultura Publ. 480 p.

Golovey M.G., 2011. Muzyka v bytiynom prostranstve M.I. Tsvetaevoy i A.I. Tsvetaevoy [Music in the Life Space of M.I. Tsvetaeva and A.I. Tsvetaeva]. Vestnik Tverskogo gosudarstvennogo universiteta. Seriya «Filologiya» [Herald of Tver State University. Series: Philology], no. 3, pp. 177-180.

Golubinaya kniga: Russkie narod. dukhovnye stikhi $X I-X I X v v$., 1991 [Pigeon Book. Russian Folk Spiritual Poems of the $11^{\text {th }}-19^{\text {th }}$ Centuries]. Moscow, Moskovskiy rabochiy Publ. 351 p.

Dutbaeva S.S., 2019. Lingvokulturologicheskie osobennosti obrazov nebesnogo mira v russkoy poezii 90-kh godov XX veka [Linguoculturological Features of the Images of the Celestial World in the Russian Poetry of the 1990's]. Vestnik Kemerovskogo gosudarstvennogo universiteta [Bulletin of Kemerovo State University], vol. 21, no. 4, pp. 1095-1104.

Zubova L.V., 1985. Traditsii stilya «pletenie sloves» u Mariny Tsvetaevoy («Stikhi k Bloku», 19161921 gg., «Akhmatovoy», 1916 g.) [Traditions of the Style "Weaving Words" by Marina Tsvetaeva ("Poems to Blok", 1916-1921, "To Akhmatova", 1916)]. Vestnik Leningradskogo gosudarstvennogo universiteta [Bulletin of Leningrad State University], no. 9, pp. 47-52.

Kolesov V.V., 1992. Kontsept kultury: obraz - ponyatiesimvol [Culture Concept: Image - Concept Symbol]. Vestnik Sankt-Peterburgskogo gosudarstvennogo universiteta. Seriya 2 [Vestnik of Saint Petersburg State University. Series 2], no. 2, pp. 3-40.

Maslova V.A., 2000. Marina Tsvetaeva: nad vremenem i tyagoteniem [Marina Tsvetaeva: Over Time and Gravity]. Minsk, Ekonompress Publ. 224 p.

Maslova V.A., 2017. Poet i kultura: kontseptosfera Mariny Tsvetaevoy [Poet and Culture: The Concept Sphere of Marina Tsvetaeva]. Moscow, FLINTAPubl. 254 p.

Moshina E.A., 2019. Mifologicheskie paralleli v metaforakh zemli $\mathrm{v}$ avtorskoy kartine mira M.I. Tsvetaevoy [Mythological Parallels in the 
Metaphors of the Earth in the Author's Picture of the World of M.I. Tsvetaeva]. Pimenova M.V., ed. Yazyki i kultura narodov Rossii i stran $S N G$ : sb. st. [Languages and Culture of the Peoples of Russia and the CIS Countries. Collected Articles]. Saint Petersburg, Izd-vo SPbGEU, pp. 91-96. (Seriya «Kontseptualnyy i lingvalnyy miry» [Series "Conceptual and Linguistic Worlds"], iss. 17).

Pimenova M.V., 2007. Kontsept serdtse: obraz, ponyatie, simvol [Concept Heart: Image, Concept, Symbol]. Kemerovo, KemGU. 500 p. (Seriya «Kontseptualnye issledovaniya» [Series "Conceptual Research"], iss. 9).

Pimenova M.V., 2011. Simvolicheskie kontsepty kak chast kontseptualnoy sistemy (na primere kontsepta tvorchestvo) [Symbolic Concepts as Part of a Conceptual System (Using the Concept of Creativity as an Example)]. Pimenova M.V., ed. Kognitivnaya lingvistika: novye paradigmy i novye resheniya: sb. st. pamyati prof. Evgeniya Aleksandrovicha Pimenova [Cognitive Linguistics: New Paradigms and New Solutions. Collection of Articles in Memory of Prof. Evgeny Aleksandrovich Pimenov]. Moscow, IYa RAN, pp. 65-83. (Seriya «Kontseptualnye issledovaniya» [Series “Conceptual Research”], iss. 15).

Pimenova M.V., Volkova E.V., 2018. Kontsept Frantsiya $\mathrm{v}$ individualno-avtorskoy kartine mira M.I. Tsvetaevoy [Concept FRANCE in M.I. Tsvetaeva's Individual Author's Picture of the World]. Gumanitarnyy vektor [Humanitarian Vector], vol. 13, no. 1, pp. 105-111.

Saakyants A.A., 1997. Marina Tsvetaeva. Zhizn $i$ tvorchestvo [Marina Tsvetaeva. Life and Creation]. Moscow, Ellis Lak Publ. 816 p.

Stenina N.A., 2004. Cheshskoe okruzhenie M. Tsvetaevoy [The Czech Environment of M. Tsvetaeva]. "Chuzhbina, rodina moya!»: Emigrantskiy period zhizni $i$ tvorchestva Mariny Tsvetaevoy: sb. dokl. XI Mezhdunar. nauch.-temat. konf. (g. Moskva, 9-12 okt. 2003 g.) ["Foreign Land, My Homeland! Emigrant Period of Life and Work of Marina Tsvetaeva". Proceedings of the $11^{\text {th }}$ International Scientific and Thematic Conference (Moscow,
October 9-12, 2003)]. Moscow, Dom-muzey Mariny Tsvetaevoy, pp. 32-41.

Feiler L., 1998. Marina Tsvetaeva: per. s angl. [Marina Tsvetaeva. Translated from English]. Rostovon-Don, Feniks Publ. 416 p.

Shveytser V.A., 1992. Byt i Bytie Mariny Tsvetaevoy [Life and Existence of Marina Tsvetaeva]. Moscow, Interprint Publ. 544 p.

Shveitser V.A., 2002. Marina Tsvetaeva [Marina Tsvetaeva]. Moscow, Molodaya Gvardiya Publ. $591 \mathrm{p}$.

Shevelenko I.D., 2015. Literaturnyy put Tsvetaevoy: ideologiya, poetika, identichnost avtora $v$ kontekste epokhi [The Literary Path of Tsvetaeva: Ideology, Poetics, the Author's Identity in the Context of the Era]. Moscow, NLO Publ. 448 p.

\section{SOURCES AND DICTIONARIES}

Kratkiy tserkovnoslavyanskiy slovar [Brief Church Slavonic Dictionary]. URL: https://slovar.cc/rel/ cerkov/2320927.html (accessed 4 November 2019).

Pasternak Boris, Tsvetaeva Marina. Chrez likholetie epokhi... Pisma 1922-1936 gg. [Boris Pasternak, Marina Tsvetaeva. Through the Hard Times of the Epoch... Letters of 1922-1936]. URL: https:// books.google.ru/books?id=q7kTDgAAQBAJ\&pg (accessed 3 November 2019).

Saakyants A., Mnukhina L., eds. Tsvetaeva M.I. Sobranie sochineniy. V7t. T. 2. Stikhotvoreniya. Perevody [Tsvetaeva M.I. Collected Works. In 7 Vols. Vol. 2. Poems. Translations]. Moscow, Ellis Lak Publ., 1994. 592 p.

Saakyants A., Mnukhina L., eds. Tsvetaeva M.I. Sobranie sochineniy. V 7 t. T. 3. Poemy. Dramaticheskie proizvedeniya [Tsvetaeva M.I. Collected Works. In 7 Vols. Vol. 3. Poems. Dramatic Works]. Moscow, Ellis Lak Publ., 1994. 816 p.

Tsvetaeva M.I. Sobranie sochineniy. V7 t. T. 6. Pisma [Tsvetaeva M. I. Collected Works. In 7 Vols. Vol. 6. Letters]. Moscow, Ellis Lak Publ., 1995. 800 p.

Efron A.S., 1998. OMarine Tsvetaevoy: Vospominaniya docheri [About Marina Tsvetaeva's. Memories of Her Daughter]. Moscow, Sovetskiy pisatel Publ. 480 p. 


\section{Information About the Authors}

Marina V. Pimenova, Doctor of Sciences (Philology), Professor, Rector, University of the Foreign Languages, 12-ya liniya V.O., 13, 199178 Saint Petersburg, Russia, MVPimenova@yandex.ru, https://orcid.org/0000-0001-5918-974X

Saule S. Dutbaeva, Candidate of Sciences (Philology), Associate Professor, Department of Russian Philology, Atyrau State University named after Kh. Dosmukhamedov, Prosp. Studencheskiy, 212, 060011 Atyrau, Kazakhstan, saule_sergo@mail.ru, https://orcid.org/0000-0001-7506-279X

Elena A. Moshina, Candidate of Sciences (Philology), Associate Professor, Department of Foreign Languages, Military Academy of Logistics named after Army General A.V. Khrulev, Zakharyevskaya St., 22, 191123 Saint Petersburg, Russia, moshina@inbox.ru, https://orcid.org/0000-0002-9490-657X

\section{Информация об авторах}

Марина Владимировна Пименова, доктор филологических наук, профессор, ректор Института иностранных языков, 12-я линия B.O., 13, 199178 г. Санкт-Петербург, Россия, MVPimenova@yandex.ru, https://orcid.org/0000-0001-5918-974X

Сауле Сергоевна Дутбаева, кандидат филологических наук, ассоциированный профессор кафедры русской филологии, Атырауский государственный университет им. Х. Досмухамедова, просп. Студенческий, 212, 060011 г. Атырау, Казахстан, saule_sergo@mail.ru, https://orcid.org/0000-0001-7506-279X

Елена Анатольевна Мошина, кандидат филологических наук, доцент кафедры иностранных языков, Военная академия материально-технического обеспечения им. генерала армии А. В. Хрулева, ул. Захарьевская, 22, 191123 г. Санкт-Петербург, Россия, moshina@inbox.ru, https://orcid.org/0000-0002-9490-657X 